\title{
Articles
}

\section{Japanese EFL Learners' Pragmatic Awareness Through the Looking Glass of Motivational Profiles}

\author{
Kenji Tagashira (田頭憲二) \\ Hiroshima University \\ Kazuhito Yamato (大和知史) \\ Kobe University \\ Takamichi Isoda (磯田貴道) \\ Hiroshima University
}

Pragmatic awareness in the field of interlanguage pragmatics has been investigated using various factors: linguistic environment, overall second language proficiency, and length of residence in the target language community. In this study, on the basis of a replication of a study on pragmatic and grammatical awareness by BardoviHarlig and Dörnyei (1998), learners' motivational factors were incorporated to investigate the relationship between motivation and pragmatic awareness. Through cluster analysis, the data were analyzed from the perspective of learners' motivational profiles in order to see how the profiles affect pragmatic awareness. The results revealed that learners' motivational profiles influence not only their perception of error identification, but also their severity ratings of errors, suggesting that noticing and understanding of the pragmatic information (Schmidt, 1995) are important aspects in the future study of interlanguage pragmatics.

JALT Journal, Vol. 33, No. 1, May 2011 
動機づけ要因から見る日本人英語学習者の語用論的意識

中間言語語用論の分野において, 言語環境, 熟達度, 目標言語環境への滞在期間等の要因 と語用論的意識の関係について調査がなされてきた。本研究では, Bardovi-Harlig and Dörnyei (1998) の研究を基に, 学習者の動機づけ要因が語用論的意識に及ぼす影響を, 学習者の動機 づけプロファイリングから考察した。動機づけを連続体と捉える自己決定理論に基づき, クラス 夕分析を用いて学習者を4つのクラスタに分類した。その結果, 文法的誤りへの気づきはクラス 夕間に違いはなかつたが、より自律的である学習者ほど, 語用論的誤りへの気づき度が高いこと が明らかとなった。このことより, より自律的な学習者であるほど, 形式へのnoticingから, 語用 論的内容を含めたunderstandingへの意識の移行 (Schmidt, 1995)がなされていることが示唆され た。

I $\mathrm{n}$ the field of Interlanguage Pragmatics (ILP), the relationship between learners' pragmatic and grammatical awareness has been the topic of an ongoing discussion since the seminal study of Bardovi-Harlig and Dörnyei (1998), which compared learners' pragmatic and grammatical awareness from the perspective of the learning environment (i.e., EFL or ESL) and the learners' overall L2 proficiency. Their successors in this type of research have dealt with the same variables (e.g., Niezgoda \& Röver, 2001) as well as other variables such as the length of residence in the ESL environment (e.g., Ran, 2007; Schauer, 2006; Xu, Case, \& Wang, 2009). However, only a few researchers have taken into account learners' individual differences within this line of study. One of these can be found in the interlanguage pragmatic instruction studies by Takahashi $(2001,2005)$, which examined how motivational factors influence learners' attention in processing the target pragmalinguistic features in the instructional sequence. However, this study focused on the form of the pragmalinguistic features and did not cover overall pragmatic awareness. The current study, therefore, attempts to directly examine the relationship between pragmatic awareness and one of the individual differences, the motivational profiles of Japanese EFL learners.

\section{Literature Review}

\section{Pragmatic Awareness}

Pragmatic awareness plays an important role in developing pragmatic competence. Kasper (1996) listed three conditions for the acquisition of pragmatic knowledge: "There must be pertinent input, the input has to be noticed [italics added], and learners need ample opportunities to develop a high level of control" (p. 148). In other words, to develop pragmatic competence, the learner has to notice the pragmatic information in the input 
and understand its function in the surrounding context (i.e., pragmatic awareness). It is fair to say that Bardovi-Harlig and Dörnyei (1998) were the first to investigate pragmatic awareness by analyzing learners' ability to recognize grammatical and pragmatic errors, and the variables that play key roles in pragmatic awareness have become an issue since then. BardoviHarlig and Dörnyei investigated the recognition of grammatical errors and pragmatic infelicities by ESL learners in the US as well as EFL high school learners and teachers of English in Hungary. Participants first watched a video comprising 20 scenarios, some of which contained either grammatical or pragmatic errors, and were subsequently asked via a questionnaire to evaluate the severity of the perceived linguistic/pragmatic problems for each error. The ESL learners recognized a considerably higher number of pragmatic errors than grammatical ones, whereas the EFL group was more aware of grammatical violations than of pragmatic ones. The severity ratings for the two error types also indicated a difference in perceptions across the two learning environments: ESL learners considered the pragmatic infelicities to be more serious, whereas EFL learners perceived the grammatical errors to be more salient.

Niezgoda and Röver (2001) replicated Bardovi-Harlig and Dörnyei's (1998) study with ESL learners in Hawaii and EFL learners in the Czech Republic and obtained contrasting results: The EFL learners recognized a higher number of pragmatic infelicities than the ESL learners. The EFL learners also assigned higher severity ratings to both the pragmatic and grammatical violations than did the ESL learners. Thus, Niezgoda and Röver's data show that the EFL learners in their study were more aware of pragmatic infelicities than the ESL learners were and also perceived those infelicities to be more serious than the ESL learners did. One agreement with the original study is that ESL learners considered pragmatic errors more salient than grammatical violations.

Overall, these previous findings showed that ESL learners recognize pragmatic errors and rate them more severely than grammatical errors (Bardovi-Harlig \& Dörnyei, 1998; Niezgoda \& Röver, 2001). More complex results, however, have been obtained for EFL learners. Bardovi-Harlig and Dörnyei (1998) found that EFL learners recognize more grammatical errors and rate them more severely, which led them to conclude that language environment is the most important factor accounting for pragmatic and grammatical awareness. Niezgoda and Röver (2001), on the other hand, found no significant differences in their replication study and argued that the "explanation lies in an interaction between exposure to pragmatic and 
grammatical input and individual learner characteristics, specifically the degree to which learners attend to input" (Niezgoda \& Röver, 2001, p. 77). The Czech-speaking EFL learners who took part were highly motivated to seek pragmatic input in their daily lives, and this motivation toward English language learning might have increased their sensitivity to pragmatic errors as well as grammatical errors.

\section{Motivation and Pragmatic Awareness}

The importance of motivation in interlanguage pragmatics is found in one of twelve basic questions proposed by Kasper and Schmidt (1996): Do motivation and attitude make a difference in level of acquisition? Their answer is as follows:

[It] is possible that intrinsic motivation (enjoyment of learning for its own sake) might be more relevant for ILP than extrinsic motivation (learning motivated by external reward), but then again intrinsic motivation might not be especially relevant because it is cognitive involvement and enjoyment rather than social involvement that is highlighted by the construct. (pp. 161-162)

In other words, motivational factors may play a role in pragmatic development. However, only a few previous studies have dealt with motivation and pragmatic awareness to support this proposal explicitly.

The first studies to examine the effects of motivation on L2 pragmatics were by Takahashi, 2001 (as cited in Kasper and Rose, 2002) and 2005. The studies investigated the possible constraints on individual difference variables, in particular learners' motivation, on the processing of L2 pragmatic input in pragmatic instruction. Takahashi (2005) used the Motivation Questionnaire adapted from Schmidt, Boraie, and Kassabgy (1996). This instrument contains 47 items that are categorized into seven subscales of motivation (i.e., intrinsic motivation, extrinsic motivation, personal goals, anxiety, expectancy/control components, attitudes, and motivational strength). The findings showed that the learners' awareness of the target pragmalinguistic features in the input correlated with their motivation-in particular, intrinsic motivation-but not with their proficiency.

One drawback of Takahashi's approach toward motivation (and possibly also that of Schmidt, Boraie, \& Kassabgy, 1996) is that motivational factors are analyzed quite arbitrarily because the researchers had to carry out fac- 
tor analysis in order to reorganize the extensive subscales of motivation set out in the questionnaire. Takahashi (2005) carried out factor analysis on the data collected from this questionnaire and obtained nine factors, which was a different configuration from that in Schmidt, Boraie, \& Kassabgy. Although Takahashi mentioned "a complex interplay between learners' motivational dispositions and their attentional targets at the pragmatic level" (p. 111), she further argued that "one can assume that learners with this motivational orientation [intrinsic motivation] perceive these pragmalinguistic forms as ones that allow them to achieve their language learning goals successfully, resulting in greater attention to these features" (p. 112) and she simply concluded that pragmatic awareness "is associated with the learners' motivation, in particular, their intrinsic motivation" (p. 113). This could result in simple dichotomous categories of motivation (intrinsic vs. extrinsic) and clearly shows that motivation needs to be understood through a systematic model.

\section{Motivation as a Developmental Continuum-Self-Determination Theory}

In order to overcome the drawback mentioned above, the authors suggest the introduction of a psychological approach so that the notion of motivation can be captured systematically and viewed along a developmental continuum.

As an elaboration of the intrinsic/extrinsic paradigm, Deci and Ryan (1985) introduced Self-Determination Theory (SDT), which focuses on various types of intrinsic and extrinsic motivation (see also, Deci \& Ryan, 2002; Hiromori, 2006). In this theory, amotivation, extrinsic motivation, and intrinsic motivation are ordered along a self-determination continuum, not as simple dichotomous categories (as seen in Figure 1).

\begin{tabular}{lc|ccc|c}
\hline $\begin{array}{l}\text { Type of } \\
\text { motivation }\end{array}$ & Amotivation & \multicolumn{3}{|c|}{ External motivation } & $\begin{array}{c}\text { Intrinsic } \\
\text { motivation }\end{array}$ \\
\cline { 2 - 5 } $\begin{array}{l}\text { Type of } \\
\text { regulation }\end{array}$ & Non-regulation & $\begin{array}{c}\text { External } \\
\text { regulation }\end{array}$ & $\begin{array}{l}\text { Introjected } \\
\text { regulation }\end{array}$ & $\begin{array}{l}\text { Identified } \\
\text { regulation }\end{array}$ & $\begin{array}{c}\text { Intrinsic } \\
\text { motivation }\end{array}$ \\
\cline { 2 - 5 } $\begin{array}{l}\text { Quality of } \\
\text { behaviour }\end{array}$ & $\begin{array}{c}\text { Non self- } \\
\text { determined }\end{array}$ & & & $\begin{array}{c}\text { Self- } \\
\text { determined }\end{array}$ \\
\hline
\end{tabular}

Figure 1. The Self-Determination Continuum

(Based on Deci \& Ryan, 2002; Hiromori, 2006, p. 34) 
The lowest level of self-determination, amotivation, refers to the state of having little or no intention to attempt the behaviour. Deci and Ryan (1985) classify extrinsic motivation according to level of internalization. External regulation refers to the least self-determined form of extrinsic motivation, including the classic instance of being controlled by external sources such as rewards or threats. A partially internalized type of extrinsic motivation, introjected regulation, exists within the person but is not considered part of the integrated self (e.g., learning English in order not to feel guilty). Identified regulation, which is the most developmentally advanced form of extrinsic motivation, involves appreciation of valued outcomes of the behaviour (e.g., learning English in order to pursue one's hobbies). The highest level of self-determination, intrinsic motivation, refers to performing behaviours out of interest or enjoyment, in other words, a state of autonomy (Dörnyei, 1998; Hiromori, 2004).

Dörnyei (1998) argues that Self-Determination Theory is superior in three ways to other motivation theories in L2 research. First, "it provides a comprehensive framework within which a large number of L2 learning orientations can be organised systematically" (p. 121). Second, SDT offers a continuum of self-determination so that the developmental process of motivational orientation can be described, and third, valid empirical evidence can be obtained through the intrinsic/extrinsic subtypes.

Although the importance of motivation in L2 learning has been commonly pointed out, few studies have dealt with the relationship between motivation and L2 pragmatic awareness, especially with a construct of motivation focusing on its development, and the impact of the learners' level of selfdetermination (i.e., autonomous self-regulation) on pragmatic awareness or pragmatic development therefore remains unclear. Accordingly, the present study adopts its framework of motivation from psychology and applies it to the field of pragmatic awareness in interlanguage pragmatics.

\section{Objective of the Study}

The objective of this study is to clarify whether there is any difference in the pragmatic awareness of Japanese EFL learners in accordance with their motivational profiles based on the systematic psychological approach SDT. The research questions, formulated to test the effects of learners' motivation on L2 pragmatic awareness in the Japanese EFL environment, were:

1. To what extent do Japanese EFL learners' patterns of motivation influence their pragmatic awareness? 
2. In what way are these differences caused by learners' motivational profiles in terms of error recognition or error severity rating for pragmatic errors?

\section{Method}

\section{Participants}

The participants were 162 Japanese university EFL learners (124 male and 38 female) who had learned English for at least 6 years as a compulsory subject at school in Japan. Since their two universities were considered to be academically intermediate institutions in Japan, and they had gone through the entrance examinations including English, their English proficiency level was considered intermediate. Table 1 presents their self-evaluated English proficiency, based on their responses to a questionnaire administered at the time of the experiment using a rating scale of 1 to 10 for the self-assessed ratings $(1=$ minimum, $10=$ near-native $)$.

Table 1. Participants' Background Information on English Language
Experience $(N=162)$

\section{Materials and Procedure}

Two questionnaires were used as data-eliciting instruments: One was for measuring English learning motivation, adapted from Hiromori (2004, 2006) for Japanese EFL learners based on SDT, and the other was for pragmatic awareness, originally devised by Bardovi-Harlig and Dörnyei (1998).

\section{Language Learning Motivation Scale}

The motivation questionnaire contained a total of 18 items with which the participants were asked to rate their agreement on a 5-point scale ranging 
from 1 (strongly disagree) to 5 (strongly agree) (see Appendix and Hiromori, 2006 for details). It took approximately 20 minutes to complete. All instructions were in their L1, Japanese.

\section{Questionnaire for Pragmatic Awareness}

The original pragmatic awareness survey was made up of 20 scenes falling into three categories: (a) eight scenarios which were grammatical but pragmatically inappropriate in the final line of the dialogues (i.e., pragmatically incorrect items), (b) eight scenarios which were pragmatically appropriate, but contained grammatical errors (i.e., ungrammatical items), and (c) four scenarios containing both grammatically correct and pragmatically appropriate sentences (see Bardovi-Harlig \& Dörnyei, 1998, for detailed items). As was done in the Bardovi-Harlig and Dörnyei study, 14 out of 20 items were used for the present analysis, treating the first five items on the questionnaire as a practice block and eliminating one invalid item (see BardoviHarlig \& Dörnyei, 1998, for a detailed explanation of the item selection).

(a) Pragmatically incorrect (5 items)

The teacher asks Peter to help with the plans for the class trip.

T: OK, so we'll go by bus. Who lives near the bus station? Peter, could you check the bus time for us on the way home tonight?

P: No, I can't tonight. Sorry.

(b) Ungrammatical (6 items)

Peter and George meet before class. They want to do something before class starts.

G: Hey, we've got 15 minutes before the next class. What shall we do?

\section{P: Let's to go to the snack bar.}

For administrative and practical reasons, instead of the videotaped format used in the original study, the test was administered through a written questionnaire (see Xu, Case, \& Wang, 2009). In addition, we made an alteration in the answer sheet from the original in order to overcome its shortcomings for analyzing the data. Figure 2 is an example of the original answer sheet used in Bardovi-Harlig and Dörnyei (1998). 
The teacher asks Peter to help with the plans for the class trip.

T: OK, so we'll go by bus. Who lives near the bus station? Peter, could you check the bus time for us on the way home tonight?

P: No, I can't tonight. Sorry.

Was the last part appropriate/correct?

Yes $\square$ No $\square$

If there was a problem, how bad do you think it was?

Not bad at all __ : _ _ _ _ __ : _ : _ Very bad

\section{Figure 2. An Example of the Answer Sheet (Bardovi-Harlig \& Dörnyei, 1998)}

In the original format, it is logically possible to tick "Yes" for a grammatically errorless yet pragmatically inappropriate scenario and vice versa. As Schauer (2006) rightly pointed out, in this format, "the researchers had to assume that when the participants indicated that there was an infelicity in a scenario, they had in fact detected the one planted by the researchers rather than identifying a 'false error'" (p. 272). In order to overcome this vagueness, we devised separate items for pragmatic and grammatical appropriateness, as shown in Figure 3.

The teacher asks Peter to help with the plans for the class trip.

T: OK, so we'll go by bus. Who lives near the bus station? Peter, could you check the bus time for us on the way home tonight?

P: No, I can't tonight. Sorry.

Was the last part ...

(a) grammatically correct? Yes $\square$ No $\square$

If your answer is no, how serious do you think it was?

Not bad at all __ : _ _ __ :__ :__ : Very bad

(b) appropriate in the situation? Yes : No :

If no, how serious do you think it was?

Not bad at all __ :__ :__ : _ _ _ _ _ Very bad

Figure 3. An Example of the Modified Answer Sheet 
In the present study, therefore, the participants were (a) asked to judge the grammatical correctness and pragmatic appropriateness of the last sentence in each scenario; if they judged the item to be grammatically incorrect or pragmatically inappropriate, they were (b) instructed to rate the severity of the error on a 6-point scale from 1 (not bad at all) to 6 (very bad).

\section{Data Analysis}

Following Bardovi-Harlig and Dörnyei's (1998) and later studies, correct error identifications were scored as 1 , and incorrect identifications were scored as 0 . For error severity ratings, the 6-point scales were assessed from 1 to 6, and participants who had not detected an error in a scenario that contained either type of error were assigned 0 . For all statistical analyses, the alpha level was set at 05 .

To examine the configurations of motivation toward English language learning, a group of multivariate statistical methods for classification known as cluster analysis was used to profile the learners based on the scores from the questionnaire. In the above-mentioned studies, the relationship between pragmatic awareness and motivation was often analyzed by correlation: The focus of analysis is on the relationship between individual variables. The current study takes a different approach to analysis in consideration of the architecture of motivation postulated by the SDT. The SDT's motivational continuum suggests that learners show different degrees of intensity on the five motivational subtypes. This theoretical underpinning required the authors to take such an approach so as to analyze the relationship between pragmatic awareness and patterns of motivational factors (i.e., motivational profiles) rather than the correlational relationship between pragmatic awareness and individual motivational factors.

In view of this requirement, the current study employed cluster analysis (see Csizér, \& Dörnyei, 2005 and Dörnyei, 2007 for further details). Based on similarities/dissimilarities of data, cluster analysis sorts subjects and items into subgroups that share homogeneous characteristics. Of the many clustering algorithms, Ward's method was used because it is generally regarded as efficient for retrieving homogeneous subgroups (Everitt, Landau, \& Leese, 2001; StatSoft, Inc., 2010). Ward's method is an agglomerative algorithm: The analysis starts with individual subjects as distinctive clusters, and larger clusters are formed by combining clusters with the closest characteristic subject until all the subjects are combined under one large cluster. This process is represented in a tree-like diagram called a dendro- 
gram. To classify the subjects, researchers need to decide the cutoff point, so that subgroups are formed below that point. This decision is exploratory in that researchers need to take into consideration changes in distances (dissimilarities) between clusters, characteristics of the resulting clusters, and the theoretical significance of the characteristics. The dissimilarity measure employed in this study was squared Euclidean distance because this is recommended for analysis using Ward's method (Hair \& Black, 2000).

\section{Results}

\section{Motivational Profiles}

The number of meaningful clusters was decided by considering large changes in clustering distances and the characteristics of the resulting clusters. With the aid of the dendrogram obtained from the English learning motivation scale, participants were categorized into four groups (see Figure 4). To confirm the validity of the grouping, separate ANOVAs were conducted and results indicated significant overall differences between each of the clusters $(p<.01$, for all).

As indicated in Figures 4 and 5, the groups were named after their characteristics: Cluster 1 moderately motivated group $(n=93)$, Cluster 2 self-determined motivation group $(n=18)$, Cluster 3 amotivated group $(n=$ $27)$, and Cluster 4 externally regulated motivation group $(n=24)$. These four motivational profile groups were used for the data analysis.

\section{Grammatical Awareness}

Table 2 shows the results of error identification and the severity rating of grammatical errors by each cluster group. Cluster 1 , the moderately motivated group, noticed errors in scenarios the most (58.24\%) and also perceived them as serious problems (average rating 2.11), followed by Cluster 4, the externally regulated motivation group, ( $54.17 \%$ and 1.94 , respectively). On the other hand, Cluster 2, the self-determined motivation group and Cluster 3 , the amotivated group were less successful, rating the severity or errors lower (53.70\% and 1.74 for Cluster 2, and $49.38 \%$ and 1.68 for Cluster 3 ). 


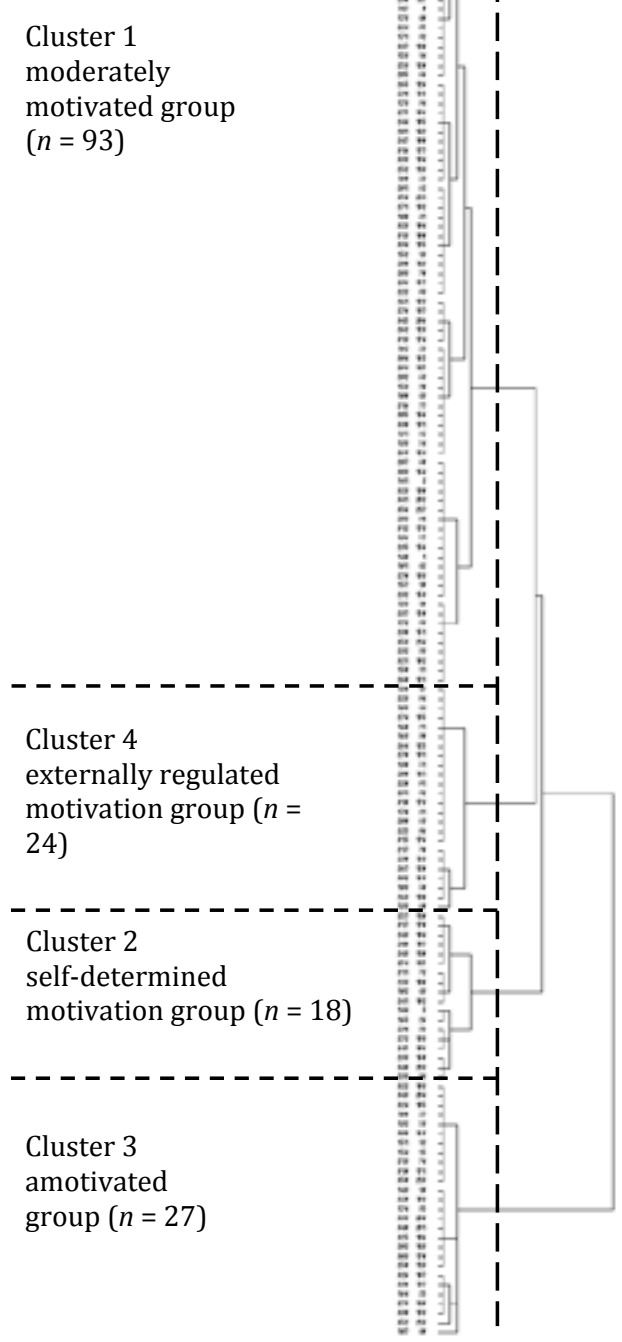

Figure 4. Dendrogram Showing the Classification of the Participants According to the English Learning Motivation Scale 


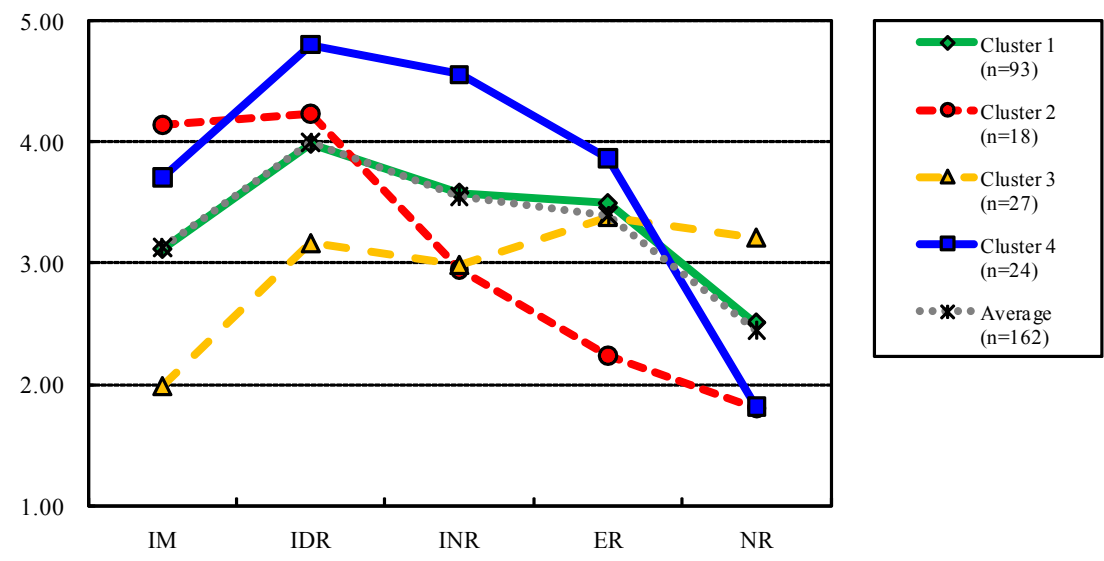

Figure 5. Motivational Profiles of the Groups of Participants

NOTE: Motivations are abbreviated as follows: IM = Intrinsic motivation, IDR = Identified regulation, $\mathrm{INR}=$ Introjected regulation, $\mathrm{ER}=$ External regulation, and $\mathrm{NR}=$ Nonregulation

Table 2. Error Identification (\%) and Severity Rating of Grammatical Errors $(N=162)$

\begin{tabular}{lccccc}
\hline & & \multicolumn{2}{c}{$\begin{array}{c}\text { Error Identifica- } \\
\text { tion (\%) }\end{array}$} & \multicolumn{2}{c}{$\begin{array}{c}\text { Severity } \\
\text { Rating }\end{array}$} \\
\cline { 3 - 6 } & & $\mathrm{M}$ & $\mathrm{SD}$ & $\mathrm{M}$ & $\mathrm{SD}$ \\
\hline $\begin{array}{l}\text { Cluster 1: Moderately motivated } \\
\text { Cluster 2: Self-determined }\end{array}$ & $(n=93)$ & 58.24 & 21.65 & 2.11 & 1.04 \\
motivation & $(n=18)$ & 53.70 & 28.90 & 1.74 & 1.08 \\
Cluster 3: Amotivated & $(n=27)$ & 49.38 & 28.30 & 1.68 & 1.08 \\
$\begin{array}{l}\text { Cluster 4: Externally regulated } \\
\text { motivation }\end{array}$ & $(n=24)$ & 54.17 & 19.81 & 1.94 & 0.87 \\
TOTAL & & 55.66 & 23.51 & 1.97 & 1.03 \\
\hline
\end{tabular}

Separate ANOVAs were conducted to see if there were any statistical differences between the scores of the groups. Results for both error identification and severity rating of grammatical errors indicated no significant differences among the clusters (error identification: $F(3,158)=0.78, p=$ .51 , severity rating: $F(3,158)=1.61, p=.19)$. This implies that, regardless of their motivational profiles, learners notice grammatical errors and perceive their seriousness. 


\section{Pragmatic Awareness}

Table 3 illustrates the results of error identification and severity rating of pragmatic errors by each motivational group. Cluster 4, the externally regulated motivation group, noticed errors in scenarios most frequently $(55.84 \%)$ and also perceived them as serious problems (2.33), followed by Cluster 2 , the self-determined motivation group $(48.89 \%$ and 2.21 , respectively). This result more or less reflects our intuition. The moderately motivated group and the amotivated group were less successful in noticing the errors and perceived them as less serious.

\section{Table 3. Error Identification (\%) and Severity Rating of Pragmatic Errors $(N=162)$}

\begin{tabular}{|c|c|c|c|c|c|}
\hline & & \multicolumn{2}{|c|}{$\begin{array}{l}\text { Error Identifi- } \\
\text { cation }(\%)\end{array}$} & \multicolumn{2}{|c|}{$\begin{array}{l}\text { Severity } \\
\text { Rating }\end{array}$} \\
\hline & & M & SD & M & SD \\
\hline Cluster 1: Moderately motivated & $(n=93)$ & 45.81 & 23.33 & 1.77 & 0.99 \\
\hline Cluster 2: Self-determined motivation & $(n=18)$ & 48.89 & 27.63 & 2.21 & 1.42 \\
\hline Cluster 3: Amotivated & $(n=27)$ & 42.96 & 18.98 & 1.73 & 0.90 \\
\hline $\begin{array}{l}\text { Cluster 4: Externally regulated motiva- } \\
\text { tion }\end{array}$ & $(n=24)$ & 55.83 & 19.54 & 2.33 & 1.01 \\
\hline TOTAL & & 47.16 & 22.80 & 1.90 & 1.05 \\
\hline
\end{tabular}

Separate ANOVAs were conducted to see if there were any statistical differences between the scores of the groups. A marginal difference among the groups was found in severity rating scores, $F(3,158)=2.63, p=.052$, but not in error identification, $F(3,158)=1.63, p=.19$. The post-hoc Tukey's HSD test revealed that in severity rating scores, the differences between Cluster 4 , (externally regulated) and Cluster 1 (moderately motivated) were not significant ( $p=.089$ ); however, the post-hoc test did present a medium-sized effect $d=.56$. Also, although the differences between Cluster 4 (externally regulated) and Cluster 3 (amotivated) were not significant ( $p=.169$ ), they presented a medium-sized effect $d=.63$.

These results suggest that, according to the patterns of learner motivation toward English language learning, while the groups are similar in recognition of pragmatic errors in the scenarios, they differ in how they perceive the appropriateness of the utterances after recognizing the errors. 


\section{Discussion}

The present study sought to explore the relationship between pragmatic awareness and motivational profiles of Japanese EFL learners. The results suggest that (a) pragmatic awareness differs according to the motivational profiles, but there is no significant difference among motivational groups in terms of their ability to identify grammatical mistakes, and (b) learners with self-determined motivation or a greater tendency toward intrinsic motivation (i.e., more self-regulated) show sharper perception of pragmatic inappropriateness in context, especially in their severity rating of pragmatic errors.

These findings, which are in accordance with Schmidt's (1993) claim that "those who are concerned with establishing relationships with target language speakers are more likely to pay close attention to the pragmatic aspects of input and to struggle to understand than those who are not so motivated" (Schmidt, 1993, p. 36), move us to ask: Why are these differences observed among the four motivationally different groups? The notions of "noticing" and "understanding" may help us understand this phenomenon. As Schmidt (1995) explains, the relationship between pragmatics and the noticing and understanding of pragmatics is as follows:

In pragmatics, awareness that on a particular occasion someone says to their interlocutor something like, "I'm terribly sorry to bother you, but if you have time could you look at this problem?" is a matter of noticing. Relating the various forms used to their strategic deployment in the service of politeness and recognizing their co-occurrence with elements of context such as social distance, power, level of imposition and so on, are all matters of understanding. (p. 30)

Noticing is a process whereby learners detect and represent a select aspect of information during input in the short-term memory so that it will be utilized for subsequent cognitive processing (Gass, 1997; Gass \& Selinker, 2008; Robinson, 1996). Gass and Selinker (2008) depict noticing (or, in their terminology, apperception) as "a priming device that prepares input for further analysis" (p. 482). In the example they cite, noticing takes place when a learner mentally represents the utterance. The subsequent stage of processing is understanding, where the noticed input is elaborated for comprehension in various aspects. There is a differing degree of understanding spanning from a simple, semantic understanding to a more elaborate, structural understanding (Gass, 1997; Gass \& Selinker, 2008; Skehan, 1998). This 
processing is exemplified by the speaker grasping the contextual meaning of the utterance by relating the noticed language (the utterance) to the social context in which it is uttered.

Previous studies such as Takahashi (2005) suggested that motivation affects noticing and, consequently, pragmatic awareness. However, no theoretical explanation is provided in the ILP studies about how the three are interrelated. The interplay of pragmatic awareness, the cognitive process of noticing and understanding, and motivation needs to be understood with reference to the function of attention, bridging the concept discussed in the cognitive domain of research and the concepts that are treated as affect. Motivation affects how learners control their attention, which is crucial for noticing and their consequent analysis of the noticed items, or understanding. To be a functional user of the target language, one needs to learn various aspects of the language including word-level features (e.g., pronunciation, orthography, meanings of a word), sentence-level features (e.g., word order and grammar), and discourse/social-level features (e.g., organization of a text and appropriate use of language in a context). Input contains relevant information for the development of the language system in all these aspects. However, as the attentional capacity of humans is limited, learners cannot process all the data in the input at one time, and they have to prioritize only what they think is important for subsequent processing by registering it in the short-term memory and discarding or setting aside the rest of the data (Robinson, 1996; Skehan, 1998; VanPatten, 1990). This trade-off is an important issue because learners can notice and understand only selected portions of linguistic information. This process is to some extent under the learner's active control and this is where motivation exerts its effects: Motivation affects learners' selective attention, that is, how they choose which aspects of incoming stimuli to attend to (Crookes \& Schmidt, 1991; Manolopoulou-Sergi, 2004; Schmidt, 1995).

Motivation, or in this study, the idiosyncratic motivational patterns within individual learners, possibly predisposes attention to different aspects of input. Learners who are motivated to attain a good command of the target language, such as those in Clusters 2 and 4, will value pragmatic aspects of language use, and they will be inclined to detect the stimuli containing pragmatic information and utilize this information for more elaborate analysis. In contrast, learners who are not willing to expend effort on learning the language, such as those in Clusters 1 and 3, will avoid deep analysis and take on a superficial processing. They will fail to attend to the same information that motivated learners elaborate on, although they might at least process 
the input at the semantic level, without relating the perceived language to the social/contextual features.

In addition to input processing, the characteristics of the externally regulated learners (Clusters 1 and 3), might lead us to highlight the effects of motivation on noticing and understanding, although this might be peculiar to the Japanese background of the subjects in this study. It is possible that those learners only value those aspects of learning that are relevant to the motives driving them toward learning. Considering the environment of EFL learning in Japan, the learners in these clusters are driven to learn English to meet academic and social pressures: Many people in Japan, regardless of their interest in the language, are required to learn English for academic and vocational purposes, and are invariably required to show their ability in English in the form of test scores. Learners in Japan are keen to perform well on school tests, as required by school curricula, or socially recognized tests such as TOEFL and TOEIC, on which high scores are often required for a job. Learners with this type of motivation are likely to value the learning of phonology, vocabulary, and grammar because these seem relevant to success in those tests, while ignoring social aspects that are not directly tested.

Applying this concept of noticing and understanding to the groups of learners classified according to their motivational profiles in the present study, learners with intrinsic motivation or more autonomous levels of extrinsic motivation are assumed to have attained a pragmatic level of understanding, whereas those with less autonomous motivational profiles only engage a superficial level of processing. Corresponding to the selfdetermination continuum of motivation, the present results could posit that the more self-determined learners are, the deeper they can perceive and interpret an utterance in a specific situation.

\section{Concluding Remarks}

The present exploratory study confirmed that pragmatic awareness of Japanese EFL learners is clearly associated with their motivational profiles, which clarified the covert assumptions of previous studies such as Niezgoda and Röver (2001) and Takahashi (2005). It also adds to our understanding of the relationship between pragmatic awareness and motivational profiles by indicating the possibility that learners' motivational profiles influence not only their perceptions of error identification, but also their severity ratings of errors. In other words, as the learners become more self-determined, they perceive the severity of pragmatic errors in the utterance as well as identify 
the pragmatic errors themselves. In order to interpret this phenomenon, the notions of noticing and understanding proposed by Schmidt (1995) were applied, and this has lead to the conclusion that the more motivated learners (i.e., more self-determined learners) reach the realm of understanding over noticing. This result is substantially different from results based on the usual conception of a simple dichotomous relationship (intrinsic vs. extrinsic motivation). In the present study, since SDT allowed us to interpret the participants' pragmatic awareness from a developmental viewpoint, the results revealed the interesting phenomenon that the intrinsically motivated (Cluster 2), presumably the best group, did not perceive pragmatic inappropriateness as well as the less intrinsically motivated (Cluster 4) did.

Several limitations of the current study need to be addressed in future research. First, although we applied Schmidt's notions of noticing and understanding in order to interpret our findings, the detailed process that learners trace from noticing to understanding for pragmatic awareness was not discussed or described. What makes learners notice or understand pragmatic errors, or what makes learners develop those qualities, should be addressed in future research.

Secondly, in this regard, there is a great need for longitudinal qualitative/ quantitative examination of pragmatic development. In order to describe the developmental stages from noticing to understanding, the pragmatic awareness of Japanese EFL learners should be observed and described longitudinally. Qualitative approaches are also more capable of capturing indepth data over time. Employed over time, qualitative approaches allow for data focused on the mechanisms of change to be captured and explain how learners move from one stage to another. In this respect, we might uncover the mechanisms driving development from stage to stage.

Finally, in the present study, the proficiency data for participants were gathered through a self-assessed rating. These data could have been more objective, consisting of, for example, test scores from a standardized English language proficiency test, so that the interplay of individual differences including learners' motivational profiles and proficiency could have been clearer in the scope of analysis. These two factors are expected to be relatively independent because some students high in proficiency may be high or low in motivation for many reasons and vice versa. This will lead us to another research question: whether learners' proficiency or motivational profile has a larger affect on their pragmatic awareness in the EFL setting. 


\section{Acknowledgments}

This study was supported by a Grant-in-Aid for Scientific Research (C) (No. 22520565) from the Japan Society for the Promotion of Science (JSPS) to the second author. The authors wish to thank Tim Greer for his insightful feedback on earlier drafts of this manuscript and Hiroaki Maeda and Atsushi Mizumoto for their advice on statistical analysis. We are also grateful to the two anonymous reviewers for their constructive and detailed comments that helped improve the manuscript.

Kenji Tagashira is an Associate Professor at Hiroshima University. His research interests include second language vocabulary acquisition and interlanguage pragmatics.

Kazuhito Yamato is an Associate Professor at Kobe University. His research interests include teaching and learning English prosody and interlanguage pragmatics.

Takamichi Isoda is an Associate Professor at Hiroshima University. His research interests include motivation.

\section{References}

Bardovi-Harlig, K., \& Dörnyei, Z. (1998). Do language learners recognize pragmatic violations? Pragmatic versus grammatical awareness in instructed L2 learning. TESOL Quarterly, 32, 233-262.

Crookes, G., \& Schmidt, R. W. (1991). Motivation: Reopening the research agenda. Language Learning, 41, 469-512.

Csizér, K., \& Dörnyei, Z. (2005). Language learners' motivational profiles and their motivated learning behaviour. Language Learning, 55, 613-659.

Deci, E. L., \& Ryan, R. M. (1985). Intrinsic motivation and self-determination in human bahavior. New York: Plenum Publishing.

Deci, E. L., \& Ryan, R. M. (Eds.) (2002). Handbook of self-determination research. Rochester, NY: University of Rochester Press.

Dörnyei, Z. (1998). Motivation in second and foreign language learning. Language Teaching, 31, 117-135.

Dörnyei, Z. (2007). Research methods in applied linguistics. Oxford: Oxford University Press.

Everitt, B. S., Landau, S., \& Leese, M. (2001). Cluster analysis (4th ed.). London: Arnold. 
Gass, S. M. (1997). Input, interaction, and the second language learner. Mahwah, NJ: Lawrence Erlbaum Associates.

Gass, S. M., \& Selinker, L. (2008). Second language acquisition: An introductory course (3rd ed.). New York: Routledge.

Hair, J. F., \& Black, W. C. (2000). Cluster analysis. In L. G. Grimm \& P. R. Yarnold (Eds.), Reading and understanding more multivariate statistics (pp. 147-205). Washington, DC: American Psychological Association.

Hiromori, T. (2004). Motivation and language learning strategies of EFL high school students: A preliminary study through the use of panel data. JACET Bulletin, 39, 31-41.

Hiromori, T. (2006). Gaikokugo gakusyuusya no doukizuke wo takameru riron to jissen [Theories and practices for enhancing foreign language learners' motivation]. Tokyo: Taga Shuppan.

Kasper, G. (1996). Introduction: Pragmatics in SLA. Studies in Second Language Acquisition, 18, 145-148.

Kasper, G., \& Rose, K. R. (2002). Pragmatic development in a second language. Oxford: Blackwell Publishing.

Kasper, G., \& Schmidt, R. (1996). Development issues in interlanguage pragmatics. Studies in Second Language Acquisition, 18, 149-169.

Manolopoulou-Sergi, E. (2004). Motivation within the information processing model of foreign language learning. System, 32, 427-441.

Niezgoda, K., \& Röver, C. (2001). Pragmatic and grammatical awareness: A function of the learning environment. In K. Rose \& G. Kasper (Eds.), Pragmatics in language teaching (pp. 63-79). Cambridge: Cambridge University Press.

Ran, L. (2007). The relationship between linguistic proficiency and pragmatic ability. US-China Foreign Language, 5, 13-17.

Robinson, P. (1996). Consciousness, rules, and instructed second language acquisition. Frankfurt: Peter Lang.

Schauer, G. (2006). Pragmatic awareness in ESL and EFL contexts: Contrast and development. Language Learning, 56, 269-318.

Schmidt, R. (1993). Consciousness, learning and interlanguage pragmatics. In G. Kasper \& S. Blum-Kulka (Eds.), Interlanguage pragmatics (pp. 21-42). Oxford: Oxford University Press. 
Schmidt, R. (1995). Consciousness and foreign language learning: A tutorial on the role of attention and awareness in learning. In R. Schmidt (Ed.), Attention and awareness in foreign language learning (pp. 1-63). Honolulu: University of Hawaii, Second Language Teaching and Curriculum Center.

Schmidt, R., Boraie, D., \& Kassabgy, O. (1996). Foreign language motivation: Internal structure and external connections. In R. Oxford (Ed.), Language learning motivation: Pathways to the new century (Technical Report No. 11, pp. 9-70). Honolulu: University of Hawaii, Second Language Teaching and Curriculum Center.

Skehan, P. (1998). A cognitive approach to language learning. Oxford: Oxford University Press.

StatSoft, Inc. (2010). Electronic statistics textbook. Retrieved from http://www. statsoft.com/textbook/

Takahashi, S. (2001). The role of input enhancement in developing pragmatic competence. In K. Rose \& G. Kasper (Eds.), Pragmatics in language teaching (pp. 171199). Cambridge: Cambridge University Press.

Takahashi, S. (2005). Pragmatic awareness: Is it related to motivation and proficiency? Applied Linguistics, 26, 90-120.

VanPatten, B. (1990). Attending to content and form in the input: An experiment in consciousness. Studies in Second Language Acquisition, 12, 287-301.

$\mathrm{Xu}, \mathrm{W}$. , Case, R. E., \& Wang, Y. (2009). Pragmatic and grammatical competence, length of residence, and overall L2 proficiency. System, 37, 205-216. 


\section{Appendix}

Sample items of the English learning motivation scale used in the study

a) Intrinsic motivation (4 items)

Sample: Because learning English is fun.

b) Identified regulation (4 items)

Sample: Because I want to obtain English skills that will be useful in the future.

c) Introjected regulation (3 items)

Sample: I learn English in order not to feel regret later on.

d) External regulation (3 items)

Sample: Because I want to get a good grade.

e) Amotivation (4 items)

Sample: I don't see what I gain from English classes. 